\title{
Does Women's Reproductive Health and Empowerment Affect Female Labor Participation in ASEAN?
}

\author{
Salma Audiena Al Faziah, Izza Mafruhah, Julianus Johnny Sarungu \\ Faculty of Economics and Business, Universitas Sebelas Maret \\ Corresponding Author: salma.alfaizah@gmail.com
}

Recieved: February 2020 | Revised: March 2020 | Accepted: April 2020

\begin{abstract}
This research aims to analyze the effect of women's reproductive health and women's empowerment on female labor force participation (FLFP) in ASEAN countries. This type of research is quantitative research with panel data types from 9 (nine) ASEAN countries during the period 2010-2017. The results show that countries with high levels of women's reproductive health and women's empowerment also have high levels of female labor participation.
\end{abstract}

Keywords: gender inequality, female labor participation, women's reproductive health, women's empowerment, panel data analysis

JEL classification: A1, C5, J8

How to Cite: Al Faziah S. A., Mafruhah I., Sarungu J., J. (2020). Does Women's Reproductive Health and Empowerment Affect Female Labor Participation in ASEAN?. Jurnal Ekonomi Pembangunan: Kajian Masalah Ekonomi dan Pembangunan, 21(1). 32-39. doi:https://doi.org/10.23917/jep.v21i1.10387

DOI: https://doi.org/10.23917/jep.v21i1.10387

\section{Introduction}

United Nations Development Programme (UNDP) explained that Sustainable Development Goals or SDGs are a program to achieve a better and more sustainable future for future generations. One of the scopes in SDGs is gender. The SDGs related to gender equality while also explaining that there are several key indicators of gender mainstreaming including: 1) education; 2) political / parliamentary participation; 3) reproductive health; 4) labor force participation. These indicators are also elements forming a gender inequality index (GII). GII has three main dimensions, namely: reproductive health, empowerment, and economic opportunities. (Gonzales, Jain-Chandra, Kochhar, Newiak, \& Zeinullayev, 2016)

Nowadays, FLFP (female labor force participation) is not only demands equal rights but also states that their functions have meaning for the development of a country. Seeing the potential of women as human resources, the effort to include women in the development process is not just mere humanity, but it is an efficient action because without including women in the development process means waste and negatively influences the speed of economic growth. Trend of data on the FLFP in the ASEAN nine countries from 2010 to 2017 is found in Figure 1.1

Figure 1.1 represents the trend of FLFP in ASEAN during 2010-2017. Indonesia and Laos are among the countries with relatively stable fluctuations in the level of female labor force participation from year to year when compared to other countries. The countries with the highest level of female labor force participation rates from 2010-2017 are Vietnam, Malaysia and Singapore. Meanwhile, groups of countries with a level of female labor force participation that tends to decline from 2010-2017 include: the Philippines, Myanmar, Thailand and Cambodia. 


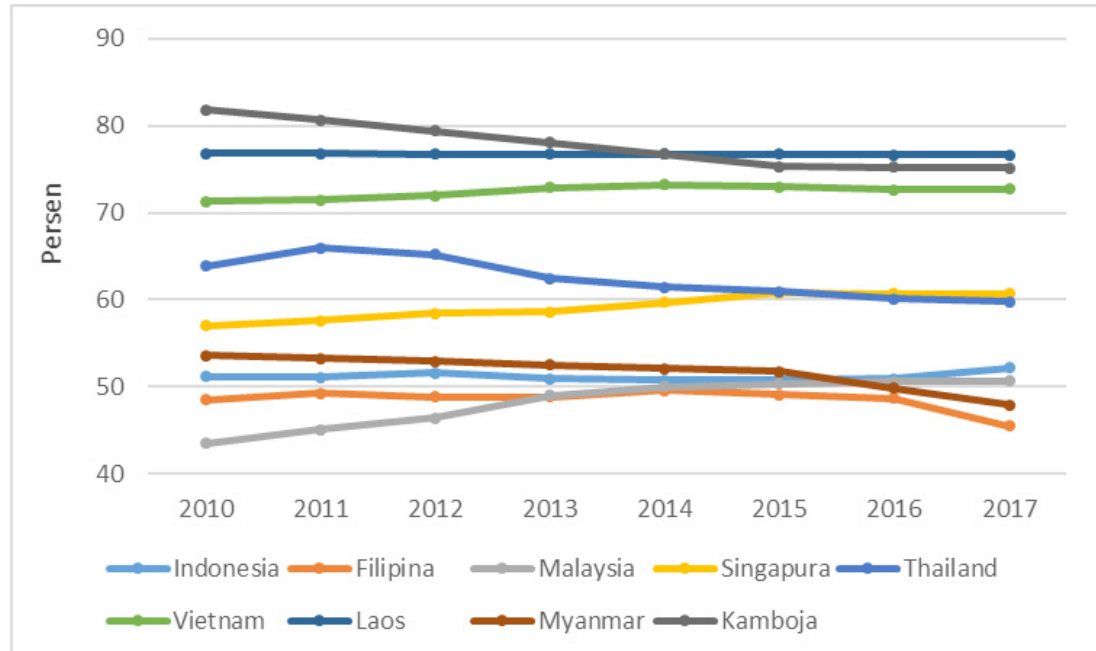

Figure 1.1 Trend of FLFP in ASEAN countries from 2010-2017 Source: UNDP Data, 2018

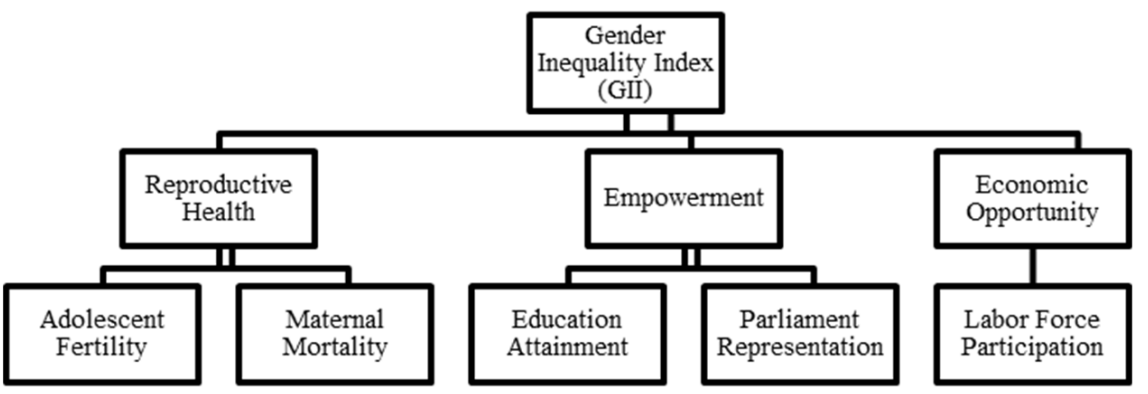

Figure 1.2 United Nations Gender Inequality Index: Dimensions and Indicators.

Source: UNDP Human Development Report, 2011

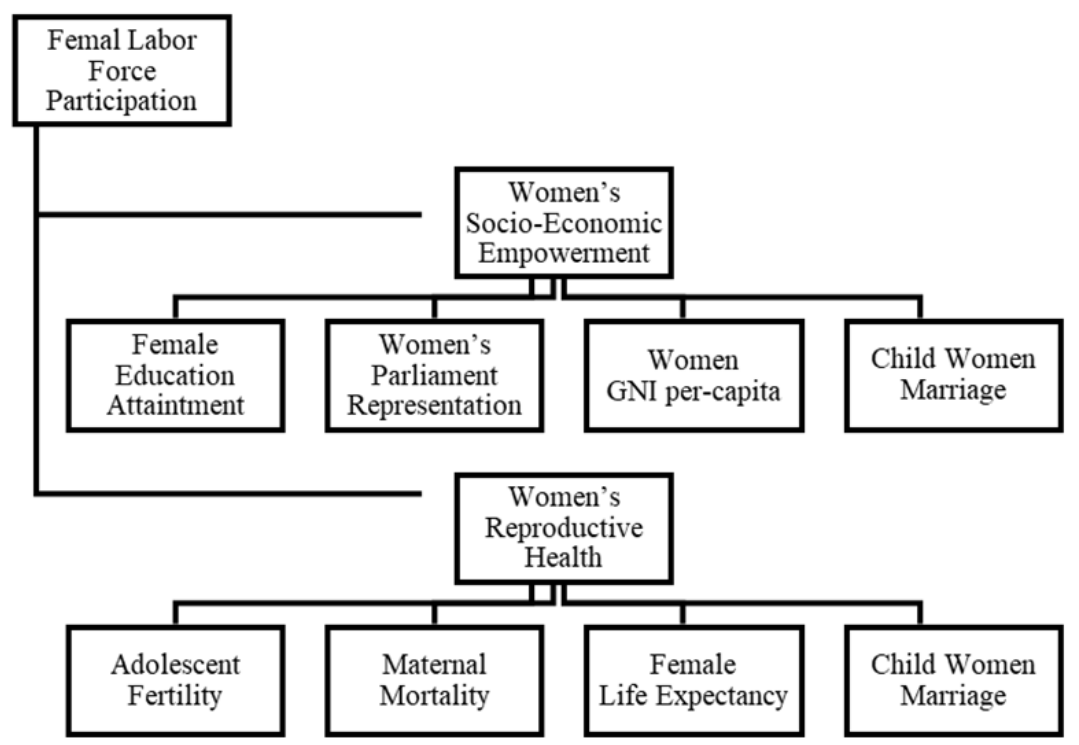

Figure 1.3 Modification of GII: Dimensions and Indicators.

Source: Cai, L. (2010). Lv, Z., \& Yang, R. (2018). Mishra, V., \& Smyth, R. (2010). Tam, H. (2011) 
The country with the highest level of female labor force participation is Cambodia despite a decline from 2010-2017. The average level of female labor force participation in Cambodia is $77.81 \%$. Meanwhile, the country with the lowest average female labor force participation rate is Malaysia but Malaysia has experienced an increase in female labor force participation from year to year. The average level of female labor force participation in Malaysia is $48.18 \%$.

UNDP Human Development Report explains that GII is measured based on the economic dimension, the social dimension of empowerment and the reproductive health dimension. The economic dimension includes labor participation. The social dimensions of empowerment include: educational attainment and one's participation in parliament / politics. Meanwhile, the dimensions of reproductive health include: mortality ratio and fertility rate. GII also has the disadvantage of combining indicators that compare men and women with indicators that only relate to women. (Gonzales et al., 2016)

Figure 1.2 represents the framework of indicators and dimensions of the GII by combining indicators that compare men and women with indicators that are only related to women. Therefore, we make modifications to the GII theoretical framework by separating variables that are only related to women, can seen in Figure 1.3

Based on the description above, this research is important in economic development because gender equality in terms of health, education, politic, especially in economy is one of the sustainable development goals.

\section{Research Method}

This study sets out to address the gap in the literature by seeking to answer the research question: whether women's reproductive health and women's empowerment affect female labor participation? We use sample of ASEAN nine countries with data covering the years from 2010 to 2017. Brunei Darussalam excluded from the main sample since their complete data sets were not available. The choice of sample selected for this analysis is primarily dictated by the availability of reliable data. The dependent variable in this analysis is FLFP (female labor force participation) which is obtained from the International Labor Office (ILO). FLPR is defined as the number of female labor participants of age 15-64 divided by the total female population of the same age group (15-64), and labor force participation is defined as employed (paid and unpaid family workers) plus unemployed (actively seeking work).

This study uses a set of static panel estimation models to examine the effect of various independent variables to estimate female labor participation at the state-level. The static panel estimation models are various ordinary least squares (OLS) models with different specification (Salari \& Javid, 2019). There are many independent variables that may impact on female labor participation so this study employs those main variables, which are supported by previous studies (Cai, 2010; Lv \& Yang, 2018; Mishra \& Smyth, 2010; Salari \& Javid, 2019; Tam, 2011), and their data are available at the state-level. The data of all variables are obtained from World Bank Data and UNDP Data.

In this paper, consistent with previous studies (Cai, 2010; Lv \& Yang, 2018; Mishra \& Smyth, 2010; Salari \& Javid, 2019; Tam, 2011), we apply the panel data estimation model. Therefore, this study uses the following static model to estimate FLFP across states.

\section{$F L F P=f(F E A, W P R, C W M, W G P, A F$, $M M, F L E)$}

$F L F P_{i t}=\alpha+\beta_{1} F E A_{i t}+\beta_{2} W P R_{i t}+\beta_{3} C W M+$
$\beta_{4} W G P_{i t}+\beta_{5} A F_{i t}+\beta_{6} M M_{i t}+\beta_{7} F L E_{i t}+\mu_{i t}$

There are unit differences and the magnitude of the independent variable in the equation so that a regression must be made with a logarithmlinear (log) model. Thus the base-line econometric model has the following form: 
Jurnal Ekonomi Pembangunan: Kajian Masalah Ekonomi dan Pembangunan, 21 (1), 2020, 32-39

$L F L F P_{i t}=a+\beta_{1} L F E A_{i t}+\beta_{2} L W P R_{i t}+\beta_{3} L C W M$

$+\beta_{4} L W G P_{i t}+\beta_{5} L A F_{i t}+\beta_{6} L M M_{i t}+\beta_{7} L F L E_{i t}$

$+\mu_{i t}$

Notes:

LFLFP : Log of female labor participation

LFEA : Log of female education attaintment

LWPR : Log of women's parliament representation

LCWM : Log of young married women

LWGP : Log of women's income per capita

LAF : Log of women's fertility rates

LMM : Log of maternal mortality ratio

LFLE : Log of women's life expectancy

a : Parameter to be estimated

$\beta \quad:$ Coefficient intercept/slope

$\mu \quad$ : Error terms $\mathrm{i} / \mathrm{t} \quad$ : Country/Year

(3) 4. Result And Discussion

\subsection{Result}

The main regression results are reported in Table 2. Column 1 shows the results from simple static random-effects specifications. WPR, WGP, $\mathrm{AF}$, and FLE has a positive and statistically significant effect on FLFP at the 10\% level. Both the female education attaintment and young women marriage are negative and statistically significant at the $10 \%$ level. As expected, high women's reproductive health and high level of women's empowerment increase FLFP, whereas variable maternal mortality is statistically not significant.

Table 1. Panel Regression Estimation Model Results.

\begin{tabular}{|c|c|c|c|c|}
\hline Variabel & (1) & (2) & (3) & (4) \\
\hline \multicolumn{5}{|l|}{ LogFLFP } \\
\hline \multirow[t]{2}{*}{ LogFEA Education } & -0.1997 & 0.2808 & -0.1288 & \\
\hline & $(0.000)$ & $(0.144)$ & $(0.083)$ & \\
\hline \multirow[t]{2}{*}{ LogWPR Politic } & 0.0800 & 0.01358 & 0.0388 & \\
\hline & $(0.000)$ & $(0.333)$ & $(0.011)$ & \\
\hline \multirow[t]{2}{*}{ LogCWM Marriage } & -4.6923 & -2.1643 & -2.9290 & \\
\hline & $(0.000)$ & $(0.001)$ & $(0.000)$ & \\
\hline \multirow[t]{2}{*}{ LogWGP Income } & 0.8480 & 0.3761 & 0.3954 & \\
\hline & $(0.000)$ & $(0.000)$ & $(0.000)$ & \\
\hline \multirow[t]{2}{*}{ LogAF Fertility } & 0.2819 & -0.1121 & 0.1127 & \\
\hline & $(0.000)$ & $(0.200)$ & $(0,010)$ & \\
\hline \multirow[t]{2}{*}{ LogMM Mortality } & 0.4970 & -0.0620 & 0.0988 & \\
\hline & $(0.000)$ & $(0.476)$ & $(0.208)$ & \\
\hline \multirow[t]{2}{*}{ LogFLE Life Expectancy } & 9.3060 & -3.4727 & 3.9690 & \\
\hline & $(0.000)$ & $(0.143)$ & $(0,000)$ & \\
\hline \multirow[t]{2}{*}{ Constant } & -47.9762 & 14.4268 & -18.1058 & \\
\hline & 0.000 & 0.158 & 0.001 & \\
\hline Adj R-square & $93 \%$ & $41 \%$ & $79 \%$ & \\
\hline Prob F-statistic & 0.0000 & 0.0000 & 0.0000 & \\
\hline Number of cross secion & 9 & 9 & 9 & \\
\hline Number of instruments & & & & 72 \\
\hline Breusch Pagan test $p$-value & & & & 0,0000 \\
\hline Hausman test $\mathrm{p}$-value & & & & 0.4807 \\
\hline
\end{tabular}

Notes: Here OLS regression models with different specifications. Figures under coefficient variable are $t$-values.

Breusch-Pagan test is a test used to determine which model is better to use between the common effect and random effect meodels. Hausman test is a test used to determine which model is better to use between the fixed effect and random effect models. Significant at $10 \%$. 
Column (1) presents the results from common effect model estimator has an Adj $R$-square value of $93 \%$ meaning that the independent variable is approved at $93 \%$ for the dependent variable, the remaining $7 \%$ is placed by other variables outside the model. Column (2) presents the results from fixed effect model estimator has an Adj R-square value of $41 \%$ meaning that the independent variable is approved at $41 \%$ on the dependent variable, the remaining $59 \%$ is placed by other variables outside the model. Column (3) presents the results from random effect model estimator has an Adj R-square value of $79 \%$ meaning that the independent variable is approved at $79 \%$ on the dependent variable, the remaining $21 \%$ is placed by other variables outside the model.. Column (4) presents the results from the breusch pagan test and hausman test. Breusch pagan test and hausman test show that the model follows random effect. Based on random effect results, the $\mathrm{R}$-square of $79 \%$ means that $79 \%$ the variance of the FLFP variable can be generated by the variance of independent variables in the model. The remaining $21 \%$ explained by other variables outside the model. Prob F-statistic value indicate that the model used exists, meaning that the independent variables in the model simultaneously effect on FLFP. Prob t-value indicate that partially there is only one variable has no significant effect on FLFP namely maternal mortality ratio, the other independent variables have a significant effect on FLFP.

\subsection{Discussion}

Based on the results of this study, variables in the dimensions of women's reproductive health namely the women's fertility rate, women's life expectancy, and young women marriage effect on FLFP according to previous studies (Cai, 2010; Gonzales et al., 2016; Ejaz, Khan, \& Khan, 2009)

The effect of women's fertility rate on FLFP based on statistical tests obtained a coefficient of 0.1127 showing that each $1 \%$ increase in women's fertility rate would increase female labor participation by $1.1 \%$ in ASEAN countries. This is consistent with previous research (Mishra
$\&$ Smyth, 2010) which states that there is a longer granger causal relationship between women's labor participation and the level of total fertility. It happens because high levels of youth fertility have an impact on low interest in education which then results in women entering the labor market with low skill levels, thereby increasing educational inequality, economic participation, and wage inequality between men and women. This relationship is reflected in higher levels of inequality and higher poverty rates for countries with high female fertility rates. (Gonzales et al., 2016)

The effect of women's life expectancy on FLFP based on statistical tests obtained a coefficient of 3.9690 indicating that every $1 \%$ increase in women's life expectancy would increase female labor participation by $39.6 \%$ in ASEAN. This is in line with previous research (Cai, 2010) which states that health has a positive and significant effect on labor force participation for men and women. It happens because if in a country providing supportive health facilities, equality to obtain equitable health services between men and women, the life expectancy of women in a country is increasing. The increase in women's life expectancy shown by health will in turn increase women's opportunities to participate in the workforce.

The effect of young women marriage based on statistical tests obtained a coefficient of 2.9290 showing that every $1 \%$ increase in young women marriage would reduce female labor participation rates by $29.2 \%$ in ASEAN. This is consistent with previous research (Ejaz et al., 2009) which states that the age of married women has a significant effect on female labor force participation. It happens because the increased of FLFP who marry at a young age cannot be adequately explained without taking into account changing attitudes towards women who work outside the home. Attitude becomes an important determinant of women's employment status. In particular, this finding is consistent with the interpretation that husbands' attitudes tend to be unfavorable towards women in the labor market 
when they become accustomed to a wife who is a full-time housewife.

All variables in the dimensions of women's empowerment namely women's educational attainment, women's political participation, and women's per capita income effect on FLFP according to previous research (Lv \& Yang, 2018; Sackey, 2005; Lechman \& Kaur, 2015; Tam, 2011).

The effect of women's educational attaintment on FLFP based on statistical tests obtained a coefficient of 0.1288 indicating that every $1 \%$ increase in women's educational attainment would reduce female labor participation by $1.2 \%$ in ASEAN. This is consistent with previous research (Sackey, 2005) showing the results that women's education in both urban and rural areas; both the elementary and post-primary levels have a significant negative impact on women's labor participation. It happens because based on the percentage of female labor participation in ASEAN which is dominated by developing countries, in contrast to developed countries. Second, in ASEAN more (for the formal sector) is filled by male and for certain conditions (such as unskilled workers) are also preferred by male. Meanwhile, for women more absorbed in the informal sector. Third, this finding indicates that the gender gap in developing countries in ASEAN is still high.

The effect of women's political participation on FLFP based on statistical tests obtained a coefficient of 0.0388 shows that every $1 \%$ increase in women's political participation would increase FLFP by $0.3 \%$ in ASEAN. This is consistent with previous research ( $\mathrm{Lv} \&$ Yang, 2018) showing the results that women's participation in political policy increases FLFP. It happens because when women are politically empowered to mobilize their voices and influence, they may tend to take steps or regulations, such as the area of sex work discrimination, to guarantee women's rights. This can contribute to increasing FLFP.

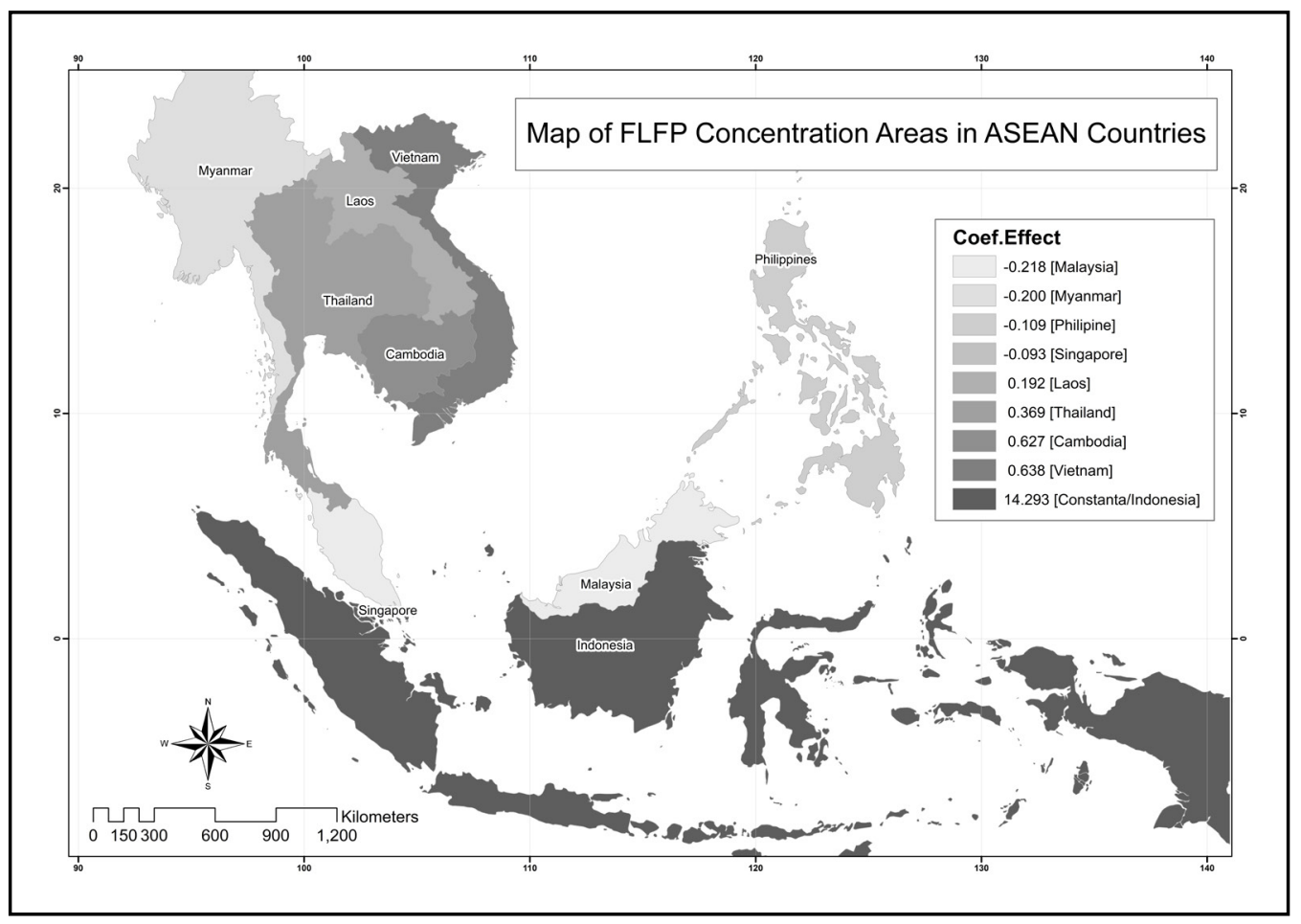

Figure 3. Map of FLFP Concentration Areas in ASEAN Countries 
The effect of women's per capita income on FLFP based on statistical tests it was obtained a coefficient of 0.3954 shows that every $1 \%$ increase in women's per capita income would increase the FLFP by $3.9 \%$ in ASEAN. This is consistent with previous research (Tam, 2011; Lechman \& Kaur, 2015) showing the results that income has a significant positive effect on the participation of the female workforce. It happens because per capita income is a measure used to describe the standard of living. Someone who has a high income per capita generally has a high standard of living. The income difference reflects the difference in quality of life: a rich person (reflected by high income per capita) has a better quality of life (reflected by, inter alia, life expectancy, health level, and education level) compared to a poor person. Thus, income reflected by the standard of living can determine a person's decision to participate or not participate in the workforce.

Based on the panel data estimation, the results can be displayed through mapping the concentration areas of FLFP in ASEAN countries, can seen in Figure 3. Figure 3 shows that the concentration of female labor force participation in the ASEAN countries varies. Vietnam and Cambodia have the highest levels of FLFP concentration. While country with the lowest level of FLFP concentration is Malaysia. In addition, countries with positive effects on FLFP in ASEAN during 2010-2017 are centered in one contiguous region. Meanwhile, countries that have a negative effect on FLFP are relatively dispersed from one another. This result and discussion can be used as a reference for governments in each country to increase the female labor participation.

\section{Conclusion}

This paper sets out to address the gap in the literature by seeking to answer the research question: whether women's reproductive health and women's empowerment affect female labor participation? Our study offers strong evidence that women's reproductive health and women's empowerment benefits FLFP. After estimating panel data regression with selected model is random effect model, our results show that from all independent variables considered there are only one variable that is not affect on FLFP, namely maternal mortality ratio. Generally, the women's parliament representation, women's per capita income, women's fertility rates, and women's life expectancy have positive effect on FLFP, while female education attaintment and young women marriage have negative effect on FLFP.

The findings could be used by national policy makers to optimize their decisions regarding the three dimension of gender inequality index (GII) including FLFP, women's reproductive health and women's empowerment. From a policy point of view, our estimation suggest that improving women's reproductive health and women's empowerment can promote female employment opportunities.

\section{References}

Badan Pusat Statistik. (2017). Penghitungan Indeks Ketimpangan Gender 2018 (Kajian Lanjutan 2). Badan Pusat Statistik. Retrieved from https://www.bps.go.id/ publication /2019/11/07/4efb3f1db4e099743a35adbd/ penghitungan-indeks-ketimpangan gender - 2018--kajian-lanjutan-2-.html

Cai, L. (2010). The relationship between health and labour force participation: Evidence from a panel data simultaneous equation model. Labour Economics, 17(1), 77-90. https://doi.org/10.1016/j.labeco.2009.04.001

Ejaz, R., Khan, A., \& Khan, T. (2009). Labor Force Participation of Married Women in Punjab (Pakistan ). 11(2), 77-106.

Gonzales, C., Jain-Chandra, S., Kochhar, K., Newiak, M., \& Zeinullayev, T. (2016). Catalyst for Change: Empowering Women and Tackling Income Inequality. Staff Discussion Notes, 15(20), 1. https://doi. org/10.5089/9781513533384.006 
Jurnal Ekonomi Pembangunan: Kajian Masalah Ekonomi dan Pembangunan, 21 (1), 2020, 32-39

Lechman,E, \& Kaur, H. (2015). Economic Growth And Female Labor Force Participation Verifying The U-Feminization Hypothesis. New Evidence For 162 Countries Over The Period 1990-2012. Economics and Sociology, Vol. 8, No 1, pp. 246-257. DOI: 10.14254/2071- 789X.2015/8-1/19

Lv, Z., \& Yang, R. (2018). Does women's participation in politics increase female labor participation? Evidence from panel data analysis. Economics Letters, 170, 35-38. https://doi.org/10.1016/j. econlet.2018.05.013

Mishra, V., \& Smyth, R. (2010). Female labor force participation and total fertility rates in the OECD: New evidence from panel cointegration and Granger causality testing. Journal of Economics and Business, 62(1), 48-64. https://doi.org/10.1016/j. jeconbus.2009.07.006

Sackey, H. A. (2005). Female Labour Force Paticipation In Ghana: The Effects Of Education Female labour force participation in Ghana: The effects of education.

Salari, M., \& Javid, R. J. (2019). How does female labor force participation impact on housing values? Research in Economics, 73(2), 129-137. https://doi.org/10.1016/j. rie.2019.03.002

Tam, H. (2011). U-shaped female labor participation with economic development: Some panel data evidence. Economics Letters, $\quad 110(2), \quad 140-142 . \quad$ https://doi. org/10.1016/j.econlet.2010.11.003

World Bank Data.(2019). Adolescent fertility rate. World Bank Data . Retrieved from https:// data.worldbank.org/indicator/

World Bank Data.(2019). Labor force participation rate, female. World Bank Data . Retrieved from https://data.worldbank.org/indicator/

World Bank Data.(2019). Life expectancy at birth, female. World Bank Data . Retrieved from https://data.worldbank.org/indicator/
World Bank Data.(2019). Maternal mortality ratio .World Bank Data . Retrieved from https://data.worldbank.org/indicator/

United Nations Development Programme. (2011). Human Development Report (Sustainability and Equity: a better future for all). United Nations Development Programme. Retrieved from https :// www.undp.org/content/undp /en/home/ librarypage/hdr/human_development report 2011.html

United Nations Development Programme. (2019). Estimated gross national income per capita, female (2011 PPP\$). United Nations Development Programme. Retrieved from http://hdr.undp.org/en/statistics/gii/

United Nations Development Programme. (2019). Gender Inequality Index (GII). United Nations Development Programme. Retrieved from http://hdr.undp.org/en/ statistics/gii/

United Nations Development Programme. (2019). Population with at least some secondary education, female (\% ages 25 and older). United Nations Development Programme. Retrieved from http://hdr.undp.org/en/ statistics/gii/

United Nations Development Programme. (2019). Share of seats in parliament (\% held by women). United Nations Development Programme. Retrieved from http://hdr. undp.org/en/statistics/gii/ 